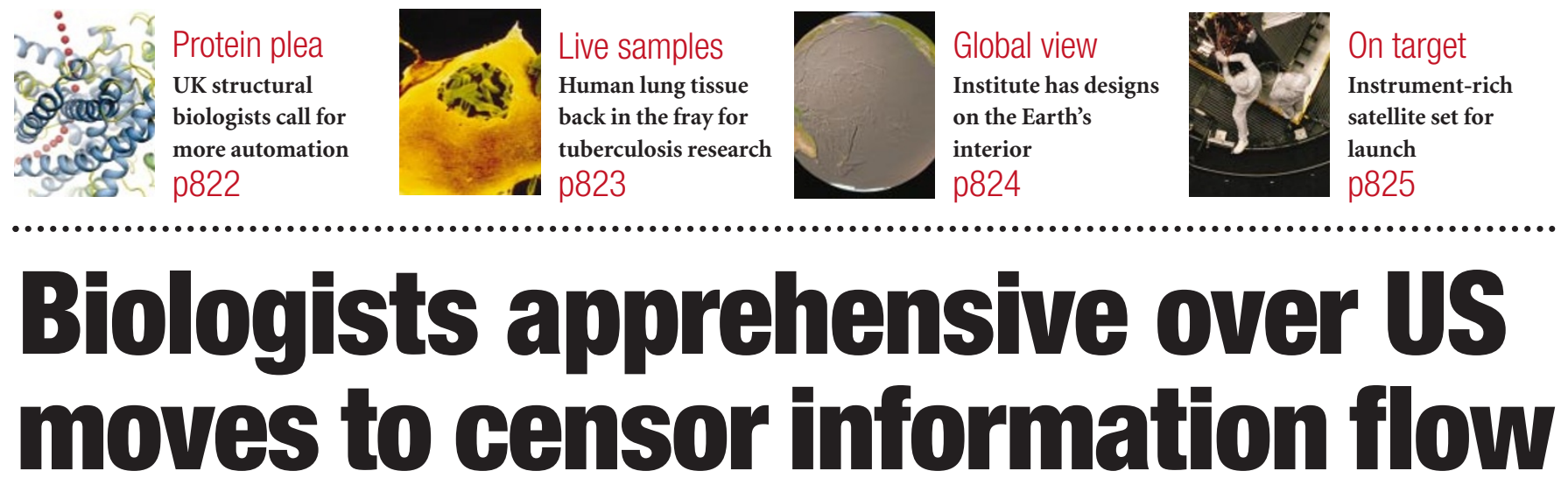

\section{Erika Check, Washington}

Fears are growing among biologists that the US government will impose new restrictions on the publication of scientific research.

Such a move has looked increasingly likely in the aftermath of last autumn's bioterrorism attacks in the United States (see Nature 415, 237; 2001).

But it has now emerged that some biologists with government funding are being encouraged to rein in the full publication of their own work. And some agencies, including the National Institutes of Health (NIH), are for the first time considering the support of classified research.

The American Society for Microbiology (ASM) says that some researchers have asked to omit certain information from the methods sections of papers to be submitted to its 11 journals. "We are in a phase of discussion that could lead to fundamental changes in the way we do science," says Ron Atlas, president-elect of the society.

Atlas says that the ASM does not intend to comply with the researchers' requests. He also says that the society is concerned about the implementation of an order signed last October by President Bush allowing the health department — including the NIH — to fund classified projects.
Anthony Fauci, head of the National Institute of Allergy and Infectious Diseases, the NIH institute most involved in research related to bioterrorism, says that his agency has not so far asked any of its researchers to keep their work secret. He adds that although most NIH-funded research should remain transparent, restricted access to some of it cannot be ruled out.

"As we move into more research on counter-bioterrorism, we should examine this issue on a case-by-case basis," Fauci says.

The possibility of restrictions riles many researchers. "Censorship would not accomplish anything but stifling beneficial work that will better prepare us to face a bioterrorism attack in the future," says Claire Fraser, director of The Institute for Genomic Research in Rockville, Maryland, which has been investigating the genome of different strains of the anthrax bacterium for the government.

The New York Times has reported that the White House will issue new guidelines on information security within the a few weeks.

US scientists are not the only ones fretting about new restrictions on their work. Some British researchers say that new export control laws under consideration in the United Kingdom include the export of information and will in theory allow government vetting of scientific material before publication.

David King, the British government's chief scientific adviser, is consulting with scientists on a response to the threat of bioterrorism, but a spokesman for the Cabinet Office declined to elaborate on any plan to restrict access to research findings.

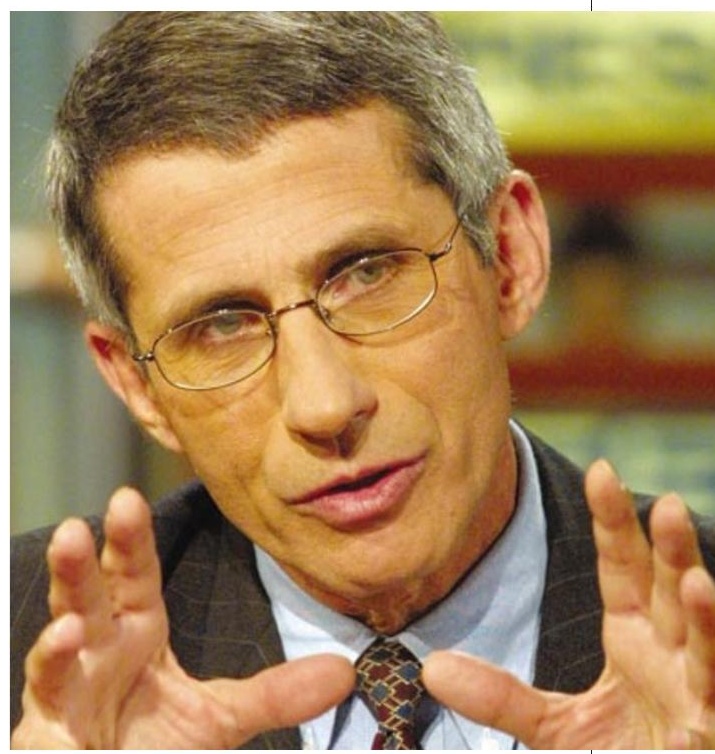

Anthony Fauci: refuses to rule out restrictions.

\title{
Bush plan deepens divide over Kyoto Protocol
}

\section{Tony Reichhardt, Washington}

Further distancing his administration from the Kyoto Protocol on climate change, President George W. Bush last week rejected the idea of reducing US greenhouse-gas emissions to below current levels.

The president's long-awaited alternative to the Kyoto plan effectively calls for no new action on the part of the United States. The Kyoto signatories pledged to cut greenhousegas emissions to below 1990 levels by 2012 . Bush instead envisions reducing the "emissions intensity" — the ratio of emissions to a nation's economic output by $18 \%$ over the same period. Using this measure, US emissions intensity dropped by about $15 \%$ in the 1990 s, although actual emissions went up by $15 \%$.

Any reductions in industrial emissions would be strictly voluntary, as mandatory caps would harm the economy, he added. Bush said that the country should reconsider this course of action in 2012 based on progress in reducing emissions and improved scientific understanding of global warming.

The new policy deepens the divide between the United States and other industrial nations, which have been more supportive of the Kyoto agreement, at least in their rhetoric. No major economy has yet ratified the protocol, but Japan may soon become the first to do so (see page 822).

US advocates of action on global warming are now set to shift their attention to the Congress, where their first objective is legislation to force corporations to report their greenhouse-gas emissions publicly. Such reporting is voluntary under the Bush plan.

Bush's statement on 14 February drew fire from environmental groups and from some in Congress. Senator Jim Jeffords (Independent, Vermont), who chairs the Senate's Environment and Public Works Committee, says the policy is "divorced from the reality of global warming". 